\title{
Analisis Potensi Daya Saing Ekonomi Kota Jambi
}

\author{
Osrita Hapsara ${ }^{1 *}$, Sudirman ${ }^{2}$ \\ ${ }^{1,2}$ Fakultas Ekonomi Universitas Batanghari Jambi \\ *Correspondence email: osritahapsara@yahoo.co.id, ${ }^{2}$ sudirmans3@yahoo.com
}

\begin{abstract}
The economic sectors of Jambi City meet 4 criteria. Based on the results of the analysis of the classical Tipologi by using the variable PDRB Jambi city as an analysis area and PDRB of Jambi Province as a reference area resulted in 11 potential economic sectors, 4 backward economic sectors, 1 superior economic sector and potential, 1 sector backward and developing. Potential economic sectors include: industrial processing, procurement of electricity and gas, water procurement, waste management, waste, construction, transportation and warehousing, provision of accommodation and eating, information and communication, real estate, corporate services, government administration, defence and compulsory social security, health services and social activities. The backward economic sectors are: agriculture, forestry, and fisheries, financial services sector and insurance, education services sector, other services. The superior and potential economic sectors are the large and retail sectors; Car repairs. The backward and growing economic sectors are the mining and excavation sectors. Based on the Location Quation sector analysis of the economic sector in Jambi city is: processing industries, electricity and gas procurement, water procurement, waste management, waste, large and retail trade; car repair, construction, transportation and warehousing, provision of accommodation and eating, information and communication, company services, government administration, defence and compulsory social security, health services and social activities. Non-agricultural bases, forestry, and fisheries, mining and excavation, financial services and insurance, education services, other services. Based on the analysis of Incremental Capital Output Ratio (ICOR) The economic sector which has high economic efficiency is mining and excavation, processing industry, construction, large and retail trade; car repair, financial services and insurance, other services. While low economic efficiency is a sector of agriculture, forestry and fisheries.
\end{abstract}

Keywords: economic sector, Incremental Capital Output Ratio

\section{Pendahuluan}

Menurut Meier (1995) dalam Kuncoro (2006), pembangunan ekonomi merupakan suatu proses dimana pendapatan per kapita suatu negara meningkat selama kurun waktu yang panjang, dengan catatan bahwa jumlah penduduk yang hidup di bawah "garis kemiskinan absolut" tidak meningkat dan distribusi pendapatan tidak semakin timpang. Peningkatan pendapatan per kapita dalam jangka panjang merupakan kunci dalam melihat suatu pengertian pembangunan ekonomi. Suatu proses pembangunan tidak terlepas dari tujuan yang ingin dicapai. Menurut Todaro (2006) proses pembangunan paling tidak memiliki tiga tujuan inti yaitu 1) peningkatan ketersediaan serta perluasan distribusi berbagai barang kebutuhan hidup yang pokok; 2) peningkatan standar hidup; dan 3) perluasan pilihan-pilihan ekonomis dan sosial. Disamping memiliki tujuan inti, pembangunan secara garis besar memiliki indikator-indikator kunci yang pada dasarnya dapat diklasifikasikan menjadi dua yaitu indikator ekonomi dan indikator sosial. Yang termasuk sebagai indikator ekonomi adalah GNP per kapita, laju pertumbuhan ekonomi, GDP per kapita dengan Purchasing Power Parity, sedangkan yang termasuk indikator sosial adalah Human Development Index (HDI) dan Physical Quality Life Index (PQLI) atau indeks mutu hidup (Kuncoro, 2006).

Menurut Lincolin Arsyad (1993:4), Pembangunan ekonomi adalah kegiatan-kegiatan yang dilakukan suatu Negara untuk mengembangkan kegiatan ekonomi dan taraf hidup masyarakatnya. Dengan batasan tersebut, maka pembangunan ekonomi pada umumnya didefinisikan sebagai suatu proses yang menyebabkan pendapatan perkapita penduduk suatu Negara meningkat dalam jangka panjang. Dari batasan dan defenisi tersebut dapat diperoleh pengertian bahwa pembangunan ekonomi adalah (1) Suatu proses, yang berarti perubahan secara terus menerus; (2) Usaha untuk menaikkan pendapatan perkapita; dan (3) Kenaikan pendapatan perkapita yang berlangsung dalam jangka panjang.

Pertumbuhan ekonomi Kota Jambi merupakan salah satu Kota yang ada di Provinsi Jambi dengan pertumbuhan ekonomi yang tinggi. Pada tahun 2013 pertumbuhan ekonomi Kota Jambi mencapai angka 7,8 persen dan pada tahun 2014 dengan pertumbuhan ekonomi 7,5 persen, namun dua tahun terakhir ini terjadi penurunan pertumbuhan ekonomi di Kota Jambi dengan rata-rata 5,25 persen. Pertumbuhan Ekonomi Kota Jambi dalam kurun waktu lima tahun terakhir puncak pertumbuhannya terjadi pada tahun 2013 dengan tingkat pertumbuhan sebesar 7,8 persen melampaui pertumbuhan ekonomi Provinsi Jambi dan secara nasional. Ditinjau dari kontribusi sektoral, komponen kontribusi sektoral PDRB Kota Jambi 2012- 2016 menunjukkan bahwa sektor Perdagangan Besar dan Enceran; Reparasi Mobil masih merupakan sektor yang memiliki kontribusi tertingggi dalam pembentukan PDRB Kota Jambi yakni rata-rata pertahun sebesar lebih dari 25,15 persen. Selain sektor sektor perdagangan besar dan eceran, Transportasi dan Pergudangan juga merupakan kontributor terbesar kedua dalam pembentukan PDRB di Kota 
Jambi rata-rata pertahun sebesar 12,65 persen, kemudian Sektor industri pengolahan sebesar rata-rata pertahun 12,45 persen . Administrasi Pemerintahan, Pertahanan juga merupakan Sektor penyumbang terbesar terhadap pembentukan PDRB Kota Jambi yaitu rata-rata 7,49 persen pertahun, Sektor ini juga didukung oleh Sektor jasa juga sebagai penyumbang terhadap pembentukan PDRB Kota Jambi rata-rata 6,16 persen pertahun.

\section{Metode}

Data yang digunakan dalam penelitian berasal dari sumber data sekunder. Data sekunder adalah data-data yang berasal dari berbagai literatur kepustakaan, artikel dalam majalah, jurnal penelitian yang berkaitan, dan sumber media massa lainnya serta hasil penelitian terdahulu. Data sekunder yang digunakan dalam penelitian berasal dari data laporan tahunan dari pihak-pihak terkait seperti Badan Perencanaan Pembangunan Daerah (Bappeda), Badan Pusat Statistik, Dinas Pekerjaan Umum, Dinas Ketenagakerjaan, Dinas Lingkungan Hidup, Bagian Ekonomi, Bagian Data dan Statistik, Badan Penanaman Modal Daerah, serta instansi terkait tahun 2012 - 2016.

\section{Teknik Analisa Data}

Teknik analisa data yang digunakan dalam penelitian ini ada beberapa metode analisis yaitu:

1. Analisis Tipologi Klassen, potensi perekonomian daerah dapat dilihat dari sisi pertumbuhan ekonominya dan konstribusi sektoral terhadap PDRBnya. Pemetaan potensi perekonomian di tujuh belas sektor lapangan usaha akan sangat bermanfaat bagi daerah untuk membuat prioritas kebijakan. Untuk menentukan prioritas kebijakan ini, khususnya kebijakan pembangunan ekonomi, diperlukan analisis ekonomi (struktur ekonomi) daerah secara menyeluruh. Salah satu analisis ekonomi tersebut adalah menggunakan tipologi klassen. Analisis Tipologi Klassen bermanfaat untuk mengidentifikasi peta potensi ekonomi secara makro. Melalui Analisis Tipologi Klassen, potensi daerah secara sektoral yang didasarkan pada data PDRB bisa dipetakan. Analisis Tipologi Klassen mengelompokan suatu sektor dengan melihat pertumbuhan (g) dan kontribusi sektor (s) tertentu terhadap total PDRB suatu daerah. Dengan menggunakan Analisis Tipologi Klassen, masing-masing sektor dapat dikelompokkan ke dalam empat kategori, yaitu:

Tabel 1.

Matriks Kategori Sektor berdasarkan Tipologi Klassen

\begin{tabular}{ccc}
\hline Kontribusi Sektor & YSEKTORAL $\geq$ YPDRB & YSEKTORAL < YPDRB \\
\hline rSEKTORAL $\geq$ rPDRB & Kuadran I & Kuadran II \\
& SEKTOR UNGGULAN & SEKTOR BERKEMBANG \\
rSEKTORAL $<$ rPDRB & Kuadran III & Kuadran IV \\
& SEKTOR POTENSIAL & SEKTOR TERBELAKANG \\
\hline
\end{tabular}

a. Sektor Unggulan/Prima (Kuadran I). Kuadran ini merupakan kuadran sektor dengan laju pertumbuhan sektor yang lebih besar dibandingkan pertumbuhan daerah (PDRB) dan memiliki kontribusi besar terhadap PDRB. Klasifikasi ini biasa dilambangkan dengan (gi) lebih besar dari (g) dan (si) lebih besar dari (s).

b. Sektor berkembang (Kuadran II). Sektor yang berada pada kuadran ini memiliki nilai pertumbuhan sektor yang lebih rendah dibandingkan dengan pertumbuhan PDRB, tetapi memiliki kontribusi terhadap PDRB daerah yang lebih besar. Klasifikasi ini biasa dilambangkan dengan (gi) lebih kecil dari (g) dan (si) lebih besar dari (s). Sektor dalam kategori ini juga dapat dikatakan sebagai sektor yang telah jenuh.

c. Sektor potensial atau masih dapat berkembang dengan pesat (Kuadran III). Kuadran ini merupakan kuadran untuk sektor yang memiliki nilai pertumbuhan sektor (gi) yang lebih tinggi dari pertumbuhan PDRB (g), tetapi kontribusi sektor tersebut terhadap PDRB (si) lebih. Klasifikasi ini biasa dilambangkan dengan gi lebih besar dari g dan si lebih kecil dari s. Sektor dalam Kuadran III dapat diartikan sebagai sektor yang sedang booming.

d. Sektor Terbelakang (Kuadran IV). Kuadran ini ditempati oleh sektor yang memiliki nilai pertumbuhan sektor (gi) yang lebih rendah dibandingkan pertumbuhan PDRB daerah (g) dan sekaligus memiliki kontribusi lebih kecil terhadap PDRB (si).

2. Analisis Location Quotient (LQ), untuk menganalisis basis ekonomi suatu wilayah, salah satu teknik yang lazim digunakan adalah location quotient (LQ). Teknik LQ digunakan untuk mengetahui seberapa besar tingkat spesialisasi sektor-sektor basis atau unggulan (leading Sektors). Dalam teknik LQ berbagai peubah (faktor) dapat digunakan sebagai indikator pertumbuhan wilayah misalnya kesempatan kerja (tenaga kerja) dan Produk Domestik Regional Bruto (PDRB) suatu wilayah. Untuk mendapatkan nilai LQ menggunakan metode yang mengacu pada formula yang dikemukakan oleh Bendavid-Val dalam Kuncoro (2004) sebagai berikut: 
$\mathrm{LQ}=\frac{V_{1}^{R} / V^{R}}{V_{1} / V}$

dimana: $V 1 R=$ Nilai PDRB suatu sektor kabupaten/kota; $V R=$ Nilai PDRB seluruh sektor kabupaten/kota; $V 1=$ Nilai PDRB suatu sektor tingkat Provinsi; $V=$ Nilai PDRB seluruh sektor tingkat Provinsi. Kriteria penilaian LQ:

a. Jika LQ lebih besar dari 1, sektor tersebut merupakan sektor basis, artinya tingkat spesialisasi kota lebih tinggi dari tingkat Provinsi.

b. Jika LQ lebih kecil dari 1, merupakan sektor non basis, yaitu sektor yang tingkat spesialisasinya lebih rendah dari tingkat Provinsi.

c. Jika LQ sama dengan 1, berarti tingkat spesialisasi kota sama dengan tingkat Provinsi.

3. ICOR (Incremental Capital Output Ratio), hubungan antara pembentukan modal dan pertumbuhan output tercermin pada indikator makroekonomi yang dikenal sebagai ICOR (Incremental Capital Output Ratio). Indikator ini menunjukkan besarnya tambahan kapital baru yang dibutuhkan untuk meningkatkan satu unit output (atau nilai tambah). Karena ICOR menunjukkan perubahan output sebagai akibat langsung dari penambahan kapital, maka ICOR bisa diformulasikan sebagai berikut:

$\mathrm{ICOR}=\frac{\Delta \mathrm{K}}{\Delta \mathrm{Y}}$

dimana: $\mathrm{K}=$ perubahan nilai kapital; $\mathrm{Y}=$ perubahan nilai output.

Dalam perkembangannya, data yang digunakan untuk menghitung ICOR bukan lagi hanya penambahan barang modal baru atau perubahan stok kapital saja, melainkan Investasi (I) yang ditanamkan, baik oleh masyarakat, pengusaha swasta maupun pemerintah, sehingga rumus ICOR dapat dimodifikasi sebagai berikut:

$\mathrm{ICOR}=\frac{1}{\Delta \mathrm{Y}}$

\section{Hasil}

Upaya untuk membangun suatu daerah, menurut teori pertumbuhan jalur cepat (turnpike), bahwa setiap wilayah perlu melihat sektor/komoditi apa yang memiliki potensi besar dan dapat dikembangkan dengan cepat, untuk mengetahui sektor potensial tersebut dilakukan dengan menggunakan hasil perhitungan Analisis Tipologi Klassen. Hasil analisa tipologi klassen, dapat ditarik ringkasan bahwa di Kota Jambi terdapat 11 sektor yang diunggulkan yaitu sektor Perdagangan besar dan eceran, reparasi mobil dan sepeda motor, sektor Transfortasi dan pergudangan, sektor Penyediaan akomodasi dan makan minum, Pengadaan Listrik dan Gas, Jasa Perusahaan, Administrasi Pemerintahan, Pertahanan dan jaminan sosial wajib, Jasa Kesehatan dan Kegiatan social, Real Estate, Informasi dan Komunikasi, Kontruksi, Pengadaan Air, Pengolahan sampah dan Limbah.

Tabel 2

Hasil Analisis Klassen Tipologi Pendekatan Sektoral Kota Jambi

\begin{tabular}{lll}
\hline \multicolumn{1}{c}{ Kontribusi Sektoral } & \multicolumn{1}{c}{ Y Sektoral $\geq$ Y PDRB } & \multicolumn{1}{c}{ Y Sektoral $<$ YPDRB } \\
\hline r sektoral $\geq$ r PDRB & $\begin{array}{l}\text { Unggulan } \\
\text { Perdagangan besar dan eceran, reparasi mobil } \\
\text { dan sepeda motor }\end{array}$ & $\begin{array}{l}\text { Perkembang } \\
\text { Pertambangan dan Penggalian }\end{array}$
\end{tabular}

r sektoral $<$ r PDRB

\section{Potensi}

1. Pertanian, Kehutanan dan Perikanan

2. Industri Pengolahan

3. Pengadaan Listrik dan Gas

4. Pengadaan Air, Pengolahan sampah dan Limbah

5. Kontruksi

6. Transfortasi dan pergudangan

7. Penyediaan akomodasi dan makan minum

8. Informasi dan Komunikasi

9. Jasa Keuangan dan Asuransi

10. Real Estate

11. Jasa Perusahaan

12. Administrasi Pemerintahan, Pertahanan dan jaminan sosial wajib

13. Jasa pendidikan

14. Jasa Kesehatan dan Kegiatan social

15. Jasa lainnya

\section{Terbelakang}

Pertambangan dan Penggalian

Sumber: PDRB Kota Jambi, Kota Jambi Dalam Angka 2016 (diolah, 2017) 
Alat analisis Tipologi Klassen digunakan untuk mengetahui gambaran tentang pola dan struktur pertumbuhan ekonomi masing-masing daerah.Tipologi Klassen pada dasarnya membagi daerah berdasarkan dua indikator utama, yaitu pertumbuhan ekonomi daerah dan pendapatan per kapita daerah. Dengan menentukan rata-rata pertumbuhan ekonomi sebagai sumbu vertikal dan rata-rata pendapatan per kapita sebagai sumbu horizontal, daerah yang diamati dapat dibedakan menjadi empat klasifikasi, yaitu: daerah cepat-maju dan cepat-tumbuh (high growth and high income), daerah maju tapi tertekan (high income but low growth), daerah berkembang cepat (high growth but low income), dan daerah relatif tertinggal (lowgrowth and low income).

\section{Analisis Location Quotient (LQ)}

Location quotient (LQ) adalah suatu perbandingan antara besarnya peran suatu sektor di Kota Jambi terhadap besarnya peran sektor tersebut di tingkat yang lebih tinggi, yaitu Provinsi Jambi..

Tabel 3

Analisis LQ Kota Jambi ADHK 2010, Tahun 2012-2016

\begin{tabular}{|c|c|c|c|c|c|c|}
\hline Lapangan Usaha & 2012 & 2013 & 2014 & 2015 & 2016 & Keterangan \\
\hline Industri Pengolahan & 1.095 & 1.031 & 1.046 & 1.036 & - & Basis \\
\hline Pengadaan Listrik dan Gas & 3.711 & 3.129 & 3.252 & 3.479 & 3.746 & Basis \\
\hline $\begin{array}{l}\text { Pengadaan Air, Pengolahan sampah dan } \\
\text { Limbah }\end{array}$ & 1.898 & 2.030 & 1.977 & 1.939 & 1.854 & Basis \\
\hline Kontruksi & 1.363 & 1.445 & 1.352 & 1.278 & 1.218 & Basis \\
\hline $\begin{array}{l}\text { Perdagangan besar dan eceran, reparasi } \\
\text { mobil dan sepeda motor }\end{array}$ & 2.857 & 2.834 & 2.978 & 2.968 & 3.069 & Basis \\
\hline Transfortasi dan pergudangan & 3.895 & 3.902 & 3.726 & 3.796 & 3.872 & Basis \\
\hline Penyediaan akomodasi dan makan minum & 2.298 & 2.329 & 2.264 & 2.171 & 2.120 & Basis \\
\hline Informasi dan Komunikasi & 1.419 & 1.343 & 1.287 & 1.295 & 1.288 & Basis \\
\hline Real Estate & 1.812 & 1.741 & 1.754 & 1.709 & 1.663 & Basis \\
\hline Jasa Perusahaan & 2.850 & 2.864 & 2.848 & 2.835 & 2.827 & Basis \\
\hline $\begin{array}{l}\text { Administrasi Pemerintahan, Pertahanan dan } \\
\text { jaminan 45ocial wajib }\end{array}$ & 2.283 & 2.231 & 2.439 & 2.676 & 2.522 & Basis \\
\hline Jasa Kesehatan dan Kegiatan sosial & 2.159 & 2.116 & 2.089 & 1.981 & 1.949 & Basis \\
\hline
\end{tabular}

Sumber: BPS Kota Jambi, (data olahan 2017)

Analisis ini digunakan untuk mengetahui sejauh mana tingkat spesialisasi sektor-sektor ekonomi di Kota Jambi atau sektor-sektor apa saja yang merupakan sektor basis atau leading sektor. Ada dua belas Sektor yang menjadi leading Sektor di Kota Jambi yaitu: Industri Pengolahan, Pengadaan Listrik dan Gas, Pengadaan Air, Pengolahan sampah dan Limbah, Kontruksi, Pengadaan Listrik dan Gas, Perdagangan besar dan eceran, reparasi mobil dan sepeda motor, Transfortasi dan pergudangan, Penyediaan akomodasi dan makan minum, Informasi dan Komunikasi, Real Estate, Jasa Perusahaan, Administrasi Pemerintahan, Pertahanan dan jaminan 45sosial wajib, Jasa Kesehatan dan Kegiatan sosial. Pada dasarnya teknik ini menyajikan perbandingan relatif antara kemampuan suatu sektor di Kota Jambi yang diselidiki dengan kemampuan sektor yang sama pada daerah yang menjadi acuan yaitu Provinsi Jambi. Satuan yang digunakan sebagai ukuran untuk menghasilkan koefisien LQ tersebut nantinya dapat berupa jumlah tenaga kerja persektor ekonomi, jumlah produksi atau satuan lain yang dapat digunakan sebagai criteria.

Tabel 4

Analisis LQ Kota Jambi ADHK 2010, Tahun 2012-2016

\begin{tabular}{lcccccc}
\hline \multicolumn{1}{c}{ Lapangan Usaha } & $\mathbf{2 0 1 2}$ & $\mathbf{2 0 1 3}$ & $\mathbf{2 0 1 4}$ & $\mathbf{2 0 1 5}$ & $\mathbf{2 0 1 6}$ & Keterangan \\
\hline Pertanian, Kehutanan dan Perikanan & 0.053 & 0.054 & 0.053 & 0.051 & 0.048 & Non Basis \\
Pertambangan dan Penggalian & 0.211 & 0.212 & 0.193 & 0.114 & 0.097 & Non Basis \\
Jasa Keuangan dan Asuransi & 0.043 & 0.042 & 0.039 & 0.038 & 0.036 & Non Basis \\
Jasa pendidikan & 0.016 & 0.015 & 0.015 & 0.016 & 0.016 & Non Basis \\
Jasa lainnya & 0.790 & 0.748 & 0.711 & 0.697 & 0.670 & Non Basis \\
\hline
\end{tabular}

Sumber: (data olahan 2017)

Sektor bukan basis di Kota Jambi adalah : Pertanian, Kehutanan dan Perikanan, Pertambangan dan Penggalian, Jasa Keuangan dan Asuransi, Jasa pendidikan, Jasa lainnya. Sektor-sektor yang menjadikan barang-barang yang dibutuhkan oleh orang yang bertempat tinggal di dalam batas perekonomian masyarakat bersangkutan. Sektorsektor tidak mengekspor barang-barang. Ruang lingkup mereka dan daerah pasar terutama adalah bersifat lokal. Bertambahnya kegiatan basis di Kota Jambi akan menambah arus pendapatan ke dalam daerah yang bersangkutan sehingga menambah permintaan terhadap barang dan jasa yang dihasilkan, akibatnya akan menambah volume kegiatan bukan basis. Sebaliknya semakin berkurangnya kegiatan basis akan menurunkan permintaan terhadap produk dari 
kegiatan bukan basis yang berarti berkurangnya pendapatan yang masuk ke daerah (Kota Jambi) yang bersangkutan. Dengan demikian kegiatan basis mempunyai peran sebagai penggerak utama

\section{Analisis Incremental Capital Output Rasio (ICOR)}

Tabel 5

Efisiensi Ekonomi Kota Jambi, Tahun 2012-2016

\begin{tabular}{|c|c|c|c|c|c|c|}
\hline \multirow{2}{*}{ No } & \multirow{2}{*}{ Uraian } & \multicolumn{5}{|c|}{ ICOR } \\
\hline & & 2012 & 2013 & 2014 & 2015 & 2016 \\
\hline 1 & Pertanian, Kehutanan, dan Perikanan & 6,04 & 6.6 & 7.13 & 7.21 & 6.98 \\
\hline 2 & Pertambangan dan Penggalian & 0,10 & 0.13 & 0.16 & 0.23 & 0.31 \\
\hline 3 & Industri Pengolahan & 0,44 & 0.85 & 0.76 & 0.61 & 0.46 \\
\hline 4 & Pengadaan Listrik dan Gas & 0,75 & 14.14 & 6.59 & 5.03 & 3.97 \\
\hline 5 & Konstruksi & 0,45 & 0.39 & 0.35 & 0.28 & 0.27 \\
\hline 6 & Perdagangan Besar dan Eceran; Reparasi Mobil da & 0,69 & 0.72 & 0.65 & 0.64 & 0.56 \\
\hline 7 & Transportasi dan Pergudangan & 0,18 & 0.18 & 0.15 & 0.1 & 0.07 \\
\hline 8 & Keuangan & 0,45 & 0.46 & 0.35 & 0.32 & 0.29 \\
\hline 9 & Jasa - jasa & 0,22 & 0.42 & 0.4 & 0.27 & 0.23 \\
\hline
\end{tabular}

Sumber: (data olahan 2017)

Efisiensi ekonomi Kota Jambi hampir pada setiap Sektor ekonomi yang ada dalam PDRB Kota Jambi hal ini terlihat dari table 5.18 diatas menunjukan efisien Sektor-sektor ekonomi di Kota Jambi diantaranya: Pertambangan dan Penggalian, ,Industri Pengolahan, Pengadaan Listrik dan Gas, Konstruksi , Perdagangan Besar dan Eceran; Reparasi Mobil, Transportasi dan Pergudangan, Keuangan, jasa-jasa. Efisiensi ini dilakukan pada semua sektor ekonomi agar masyarakat mendapat manfaat lebih besar dari kegiatan ekonomi yang berjalan di Kota Jambi, kecuali pada Sektor Pertanian, Kehutanan, dan Perikanan ini membutuhkan investasi yang besar untuk meningkatkan output pada Sektor pertanian, kehutanan dan perikanan. Pada tahun 2012 sektor pertanian, kehutanan dan perikanan jika Sektor ini ingin meningkatkan output 1 persen, ini membutuhkan investasi sebesar 6,04 persen, sedangkan pada tahun 2016 jika Sektor ini ingin meningkatkan output 1 persen maka kebutuhan investasi sebesar 6,98 persen dan rata-rata dalam kurun waktu lima tahun terakhir kebutuhan investasi intuk menaiki output 1 persen membutuhkan investasi sebesar 6,79 persen.

Tabel 6

Efisiensi Ekonomi Kota Jambi, Tahun 2012-2016

\begin{tabular}{llcccccc}
\hline No & Uraian & \multicolumn{7}{c}{ ICOR } \\
\hline 1 & PDRB & 2012 & 2013 & 2014 & 2015 & 2016 \\
& & 11.33 & 8.28 & 6.49 & 3.47 & 1.88 \\
\hline
\end{tabular}

Sumber: (data olahan 2017)

Upaya penghitungan ICOR, PDRB berserta komponen-komponennya di Kota Jambi menggunakan versi, yaitu atas dasar harga konstan (at constant price). PDRB atas dasar harga konstan menilai PDRB dan komponenkomponennya berdasarkan suatu harga pada tahun tertentu (disebut sebagai tahun dasar atau base year). Penghitungan PDRB atas atas dasar harga konstan memberikan penjelasan, salah satu, mengenai laju pertumbuhan ekonomi wilayah bersangkutan pada periode waktu tertentu, dimana diketahui kebutuhan investasi di kota jambi terhadap pembentukan nilai produksi suatu barang dan jasa yang terdapat dalam PDRB dari tahun 2012 hingga 2016 menunjukan sebuah tren yang positif dimana pada tahun 2012 jika kota Jambi inggin meningkatkan nilai PDRB 1 persen maka pemerintah Kota Jambi membutuhkan Investasi sebesar 11,33 persen, tetapi pada tahun 2013 sampai tahun 2016 jika pemerintah Kota Jambi ingin meningkatkan nilai PDRB sebesar 1 persen maka Kota Jambi hanya membutuhkan investasi rata-rata 5,03 persen angka ini jauh di bawah angka pada tahun 2012, ini menunjukan Kota Jambi mampu dalam pemilihan teknoligi produksi secara tepat dengan melihat perbandingan antara input dan output.

\section{Daftar Pustaka}

Kuncoro, 2006, Pengantar perencanaan dan pembangunan ekonomi daerah. BPFE Yogyakarta.

Arsyad Lincolin, 1993, Pembangunan Ekonomi

Porter, 1990, Pengembangan Daya Saing Daerah

Huda, M., dan Santoso, E.B. 2014. Pengembangan Daya Saing Daerah Kabupaten/Kota di Provinsi Jawa Timur berdasarkan Potensi Daerahnya. Jurnal Teknik Pomits Vol. 3, No. 2

Malhotra, N.K, 2004. Riset Pemasaran, Pendekatan Terapan. Edisi Bahasa Indonesia, PT. Indeks Kelompok Gramedia, Jakarta 
Porter, 2000. Location, competition, and economic development: local clusters in global economy. Economic development quarterly. Vol. 14 no. 1 February 2000, hal.15-34.

Santoso, E., B. 2009. Daya saing kota-kota besar di Indonesia. Makalah dipresentasikan pada Seminar Nasional Perencanaan Wilayah dan Kota, ITS, 29 Oktober. 